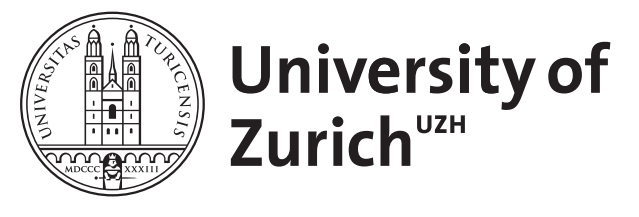

\title{
Genetics of early-onset obsessive-compulsive disorder
}

\author{
Walitza, S ; Wendland, J R ; Gruenblatt, E ; Warnke, A ; Sontag, T A ; Tucha, O ; Lange, K W
}

\begin{abstract}
Obsessive-compulsive disorder (OCD) is characterized by recurrent, intrusive and disturbing thoughts as well as by repetitive stereotypic behaviors. Epidemiological data are similar in children and adults, i.e., between 1 and $3 \%$ of the general population suffer from OCD. Children with OCD are often seriously impaired in their development. OCD, especially of early onset, has been shown to be familial. Several candidate genes of predominantly neurotransmitter systems have been analyzed and a total of three genome-wide linkage scans have been performed until now. Analyses of candidate genes in linkage regions have not provided evidence for their involvement in OCD, with the exception of the glutamate transporter gene SLC1A1 on 9p24. Genome-wide association analyses are in progress and the results will promote further independent replication studies. The consideration of subtypes regarding age of onset, symptom dimensions and/or comorbid disorders is needed.
\end{abstract}

DOI: https://doi.org/10.1007/s00787-010-0087-7

Posted at the Zurich Open Repository and Archive, University of Zurich

ZORA URL: https://doi.org/10.5167/uzh-41812

Journal Article

Published Version

Originally published at:

Walitza, S; Wendland, J R; Gruenblatt, E; Warnke, A; Sontag, T A; Tucha, O; Lange, K W (2010). Genetics of early-onset obsessive-compulsive disorder. European Child Adolescent Psychiatry, 19(3):227235 .

DOI: https://doi.org/10.1007/s00787-010-0087-7 


\title{
Genetics of early-onset obsessive-compulsive disorder
}

\author{
Susanne Walitza • Jens R. Wendland · Edna Gruenblatt • Andreas Warnke • \\ Thomas A. Sontag $\cdot$ Oliver Tucha $\cdot$ Klaus W. Lange
}

Received: 30 June 2009/ Accepted: 6 January 2010/Published online: 6 March 2010

(C) Springer-Verlag 2010

\begin{abstract}
Obsessive-compulsive disorder (OCD) is characterized by recurrent, intrusive and disturbing thoughts as well as by repetitive stereotypic behaviors. Epidemiological data are similar in children and adults, i.e., between 1 and 3\% of the general population suffer from OCD. Children with OCD are often seriously impaired in their development. OCD, especially of early onset, has been shown to be familial. Several candidate genes of predominantly neurotransmitter systems have been analyzed and a total of three genome-wide linkage scans have been performed until now. Analyses of candidate genes in linkage regions have not provided evidence for their involvement in OCD, with the exception of the glutamate transporter gene SLC1A1 on 9p24. Genome-wide association analyses are in progress and the results will promote further independent replication studies. The consideration of subtypes regarding age of onset, symptom dimensions and/or comorbid disorders is needed.
\end{abstract}

\section{S. Walitza $(\bowtie) \cdot$ E. Gruenblatt}

Department of Child and Adolescent Psychiatry,

University of Zurich, Zurich, Switzerland

e-mail: susanne.walitza@kjpdzh.ch

\section{J. R. Wendland}

Laboratory of Clinical Science,

National Institute of Mental Health, Bethesda, USA

\section{A. Warnke}

Department of Child and Adolescent Psychiatry and

Psychotherapy, University of Würzburg, Wurzburg, Germany

T. A. Sontag · K. W. Lange

Department of Experimental Psychology,

University of Regensburg, Regensburg, Germany

O. Tucha

Department of Psychology,

University of Groningen, Groningen, The Netherlands
Keywords Obsessive-compulsive disorder - Serotonin . Glutamate transporter gene - Early onset .

Brain-derived neurotrophic factor

\section{Introduction}

Obsessive-compulsive disorder (OCD) is a heterogeneous psychiatric disorder characterized by clinically significant recurrent, intrusive and disturbing thoughts (obsessions) as well as by repetitive stereotypic behaviors, which are usually associated with anxiety or dread (compulsions). OCD affects up to $3 \%$ of the population and an early age of symptom onset has been observed in many patients $[18,38$, 49]. According to the National Comorbidity Survey Replication, OCD has a median age at onset of 19 years, with $21 \%$ of all cases starting by the age of 10 years [27]. Furthermore, OCD often follows a chronic course and has a poor long-term prognosis. Pooled mean persistence rates were $41 \%$ for full OCD and $60 \%$ for full or subthreshold OCD [48]. Kessler et al. [27] have found OCD to be the anxiety disorder with the highest percentage $(50 \%)$ of serious cases. Converging evidence from various lines of research supports a causal role of the cortico-basal gangliathalamo-cortical loops that involve the orbitofrontal cortex and the anterior cingulate cortex. A review of the neurobiology of OCD is given by Grados and Wilcox [19] in their research update of genetics in OCD.

\section{Formal genetic findings}

Twin and family studies have led to a better understanding of the contribution of both genetic and environmental factors to the development of OCD. Knowledge of the 
formal genetic aspects of OCD is a prerequisite for the understanding of the results of numerous molecular genetic studies.

\section{Twin studies}

There are only a very limited number of twin studies regarding early-onset OCD and OC symptoms (see Table 1). In a study of anxiety-related behaviors, Eley et al. [15] observed a heritability of OC behavior of 0.65 in 4,564 preschool twins. Hudziak et al. [26] studied the Child Behaviour Checklist Obsessive Compulsive Scale (CBCLOCS) in a sample of the Netherlands Twins Registry (NTR) and in a second sample of the Missouri Twin Study. In the NTR sample, the authors assessed twin pairs, whose parents reported on their behavior via CBCL when they were 7,10 or 12 years of age. A total of 4,246, 2,841 and 1,562 twin pairs were available for analysis at ages 7, 10 and 12 years, respectively. The 10- and 12-year-old samples were subsets of the 7-year-old sample. In the Missouri Twin Study sample, the twins were aged 8.8-9.5 years. A total of 1,461 twin pairs were available for the analysis of CBCL-OCS. Analysis of the twin correlations yielded evidence for the influence of both genetic and environmental factors. Across age groups and the two cultures (Netherlands and USA), the additive genetic influence on the CBCL-OCS varied from 45 to $58 \%$. The variance accounted for by non-shared environmental factors ranged from 42 to $55 \%$. Only in the 12-year-old group of the NTR sample, the magnitude of the shared environmental influences was about $16 \%$.

Based on DSM-IV criteria, Bolton et al. [10] recently investigated a community sample of 854 6-year-old twins (see Table 1), whose mothers were interviewed after positive screening at age 4 using a maternal-informant composite questionnaire on anxiety related behaviors and tics. The study aimed to address whether individual differences in early-onset OCD, tics and anxiety disorders show familial aggregation effects due to either genetic or environmental influences. For the final analysis, a child was assigned a "symptom syndrome" on meeting the full DSM-IV symptom criteria for the disorder regardless of the degree of impairment, defined by the interview schedule rules [Anxiety Disorders Interview Schedule for Children and Parents (ADIS-C/P)]. To maximize the numbers, a phenotype termed "subthreshold for symptom syndrome" was also included (for more details see Bolton et al. [10]. Additive genetic effects accounted for $29 \%$ of the variance of the OCD phenotype including subthreshold cases. The estimation of familial effects due to both combined additive genetic effects and shared environmental factors, which could not be distinguished in this study, was $47 \%$. In this pediatric population, significant within-twin associations between OCD and tics as well as OCD and anxiety disorders were observed.

A review of the findings based on twin studies of children and adults was compiled by Van Grootheest et al. [50]. The authors concluded that the heritability for obsessive-compulsive symptoms ranges from 0.45 to 0.65 in children and from 0.27 to 0.47 in adults.

\section{Family studies}

First-degree relatives of patients with OCD have elevated rates of OCD as well as anxiety, mood, attention deficit/ hyperactivity and tic disorders. In earlier studies, family members were not investigated using standardized interviews. Familial rates were described using the family history method with one person (the index patient) or, in the case of children, with the mother or father providing

Table 1 Twin studies of early-onset OCD or OC symptoms

\begin{tabular}{|c|c|c|c|c|}
\hline Number of twins & Age at investigation (years) & Heritability & Instruments & Studies \\
\hline 4,564 & 4 & $\begin{array}{c}0.65 \text { for } \mathrm{OC} \\
\text { behavior }\end{array}$ & $\begin{array}{l}\text { Mother-reported } \\
\text { anxiety-related } \\
\text { behaviors }\end{array}$ & Eley et al. [15] \\
\hline $4,246^{\mathrm{a}}$ & $7^{\mathrm{a}}$ & $0.45-0.58$ & CBCL-OCS $^{\mathrm{b}}$ & Hudziak et al. [26] \\
\hline $2,841^{\mathrm{a}}$ & $10^{\mathrm{a}}$ & & & \\
\hline $1,562^{\mathrm{a}}$ & $12^{\mathrm{a}}$ & & & \\
\hline $1,461^{\mathrm{c}}$ & $8.8-9.5^{\mathrm{c}}$ & & & \\
\hline 854 & 6 & $\begin{array}{l}0.47 \text { for } \\
\text { subthreshold OCD }\end{array}$ & $\begin{array}{l}\text { DSM-IV } \\
\text { ADIS-C/P }\end{array}$ & Bolton et al. [10] \\
\hline
\end{tabular}

${ }^{a}$ The Netherlands sample was divided into three age groups

b CBCL-OCS: Child Behaviour Checklist Obsessive-Compulsive Scale

c Missouri Twin study, average age of 9 years

d Anxiety disorders interview schedule for children and parents 
information about all first-degree relatives. Although this kind of assessment probably underestimated the rate of affected relatives, the findings suggested that OCD was familial. Since the 1980s, direct interview studies have been performed, investigating as many first- and seconddegree family members as possible. Family studies showed that first-degree relatives of patients with OCD were affected by OCD considerably more frequently than relatives of healthy control subjects (see Table 2).

\section{Family studies based on children and adolescents with $O C D$}

Among the parents of children with severe OCD, Lenane et al. [30] detected OCD in $25 \%$ of the fathers and in $9 \%$ of the mothers. Riddle et al. [45] reported that 15 out of 21 (71\%) OCD children had a parent with either OCD $(N=4)$ or obsessive-compulsive symptoms $(N=11)$. Chabane et al. [11] did not find elevated rates of OCD among family members of patients with an age of onset of $>16$ years. These authors concluded that some children with OCD may show a high degree of familiality, while a considerable number show no familiality. Hanna et al. [21] examined first- and second-degree relatives of 35 children with OCD and of 17 healthy controls. The lifetime prevalences of definite OCD were significantly higher in first-degree relatives than in control relatives $(22.5 \%$ vs. $2.6 \%$; ratio: $8.65)$. The difference between case and control first-degree relatives increased on inclusion of subthreshold OCD (27.4\% vs. $2.6 \%$ ), yielding a relative risk of 10.54 . In contrast to these findings based on first-degree relatives, there were no significant differences between case and control second-degree relatives. This study, however, probably underestimated the true rate of OCD in seconddegree relatives, since the majority of them were not directly interviewed. According to the same study of Hanna et al. [21], an increase in lifetime OCD and subthreshold OCD was observed in relatives of patients with ordering compulsions compared to the relatives of OCD patients without these compulsions ( $45.4 \%$ vs. $18.8 \%$ ). Furthermore lifetime prevalence of definite OCD was significantly higher in the case of first-degree relatives with a history of tics than in the case of first-degree relatives without a tic history ( $57.1 \%$ vs. $20.9 \%)$.

Among family studies based on children with OCD, Rosario-Campos et al. [14] also reported a high rate of firstdegree relatives affected by OCD (22.7\%). The average age of the index patients was very low (onset less than 7 years) in comparison to the age of index patients in other family studies (see Table 2). Moreover, the age of onset of OCD in the index patients was correlated with that in the affected first-degree relatives [14]. In this study, the patients had high co-morbidity rates with Tourette syndrome (33\%) and tic disorders (13.2\%).

In contrast, an earlier study of Reddy et al. [44] reported a prevalence rate of $4.96 \%$ in first-degree relatives of
Table 2 Familiality in children and adults with OCD a Studies performed in samples ascertained through children with OCD

b Subthreshold OCD using DSM-III-R

c $82 \%$ of the patients had an onset prior to 18 years of age

d Including subthreshold OCD using DSM-IV

\begin{tabular}{|c|c|c|c|}
\hline $\begin{array}{l}\text { OCD in first-degree } \\
\text { relatives of index } \\
\text { patients with onset } \leq 18 \text { years } \\
(\%)\end{array}$ & $\begin{array}{l}\text { OCD in first-degree } \\
\text { relatives of index } \\
\text { patients with onset } \\
>18 \text { years }(\%)\end{array}$ & $\begin{array}{l}\text { OCD in first-degree } \\
\text { relatives of } \\
\text { controls }(\%)\end{array}$ & Studies \\
\hline 25 in mothers & & & Lenane et al. [30] ${ }^{\mathrm{a}}$ \\
\hline \multicolumn{4}{|l|}{9 in fathers } \\
\hline \multirow[t]{3}{*}{8.8} & & & Bellodi et al. [7] \\
\hline & 2.5 & 2.3 & Black et al. [8] \\
\hline & 4.9 & & Nicolini et al. [39] \\
\hline 19 & & & Riddle et al. $[45]^{\mathrm{a}}$ \\
\hline \multicolumn{4}{|l|}{$52^{\mathrm{b}}$} \\
\hline 10.3 & & 1.9 & Pauls et al. $[42]^{c}$ \\
\hline $7.9^{\mathrm{b}}$ & & $2.0^{\mathrm{b}}$ & \\
\hline 11.7 & 0 & 2.7 & Nestadt et al. [38] \\
\hline \multirow[t]{2}{*}{4.96} & & 0 & Reddy et al. [44] ${ }^{\mathrm{a}}$ \\
\hline & 3.5 & & Albert et al. [1] \\
\hline 22.7 & & 0.9 & do Rosario-Campos \\
\hline $29.2^{\mathrm{d}}$ & & $2.4^{\mathrm{d}}$ & et al. $[14]^{\mathrm{a}}$ \\
\hline 16.1 & 2.9 & & Chabane et al. [11] \\
\hline 22.5 & & 2.6 & Hanna et al. [21] $]^{\mathrm{a}}$ \\
\hline $27.4^{\mathrm{d}}$ & & & \\
\hline
\end{tabular}


juvenile patients with OCD (aged 16 years or less), while no OCD was observed among the relatives of controls. In contrast to other studies, none of the siblings of the index patients received a diagnosis of OCD and none of the firstdegree relatives had subthreshold OCD. The authors concluded that most juvenile cases of OCD were non-familial and unrelated to tic disorders. A limitation of this study was the small sample size ( 35 patients and 34 age-matched controls). Furthermore, the authors discussed that their findings of a relatively low rate of OCD in the first-degree relatives could be related to the only moderate clinical symptomatology and the relatively short duration of the illness in their index patients.

\section{Family studies based on adults with childhood or adolescent-onset $O C D$}

Bellodi et al. [7] investigated families based on index patients whose OCD commenced at different ages (21 patients with age of onset of $<14$ years of age, and 71 patients with age of onset of $>14$ years of age). The risk for OCD of all first-degree relatives was $3.4 \%$ and increased to $8.8 \%$ when patients had an onset of OCD earlier than 14 years of age. Pauls et al. [42] interviewed all available first-degree relatives of 100 patients, whose OCD onset was mainly in childhood and adolescence: 82 reported onset of OCD symptoms at or before the age of 18 years. OCD and subthreshold OCD were significantly more frequent in the patients' families in comparison to families of healthy controls (10.3 and $7.9 \%$ and 1.9 and $2.0 \%$, respectively). The rate of OCD and subthreshold OCD was approximately twice as high among the relatives of the patients with early-onset as compared with the relatives of patients with late-onset OCD (20.1\% vs. $10.9 \%)$. It is of note that most of this difference was due to the more common occurrence of subthreshold OCD among the relatives of the cases. Pauls et al. also found that first-degree relatives of patients with OCD had higher frequencies of tic disorders $(4.6 \%)$ than relatives of the controls $(1 \%)$. Nestadt et al. [38] reported an OCD prevalence rate of $11.7 \%$ in first-degree relatives of OCD patients and of $2.7 \%$ in relatives of controls. There were no affected first-degree relatives of patients with an OCD onset after the age of 17 years.

The comparatively high familiality in early versus late OCD [1, 8, 39] is illustrated in Table 2 based on both childhood and adult index patients. The wide range of prevalence rates of OCD in first-degree relatives across different studies merits discussion. Heterogeneity of the phenotype, the absence of a control group, the young age of siblings in studies of childhood OCD patients and too few directly interviewed relatives may result in over/underestimation of the prevalence of OCD in relatives.
Investigators were in some studies not blinded with respect to whether or not they were assessing relatives of cases or controls or relatives of patients with early- versus lateonset of OCD [7, 44, 45].

\section{Molecular genetic findings in OCD}

\section{Linkage studies}

Three genome-wide linkage studies of OCD have so far been published. In two of these studies, the samples were ascertained through patients with early-onset OCD $(<18$ years of age, Hanna et al. [22, 23]). In all three studies, no significant genome-wide evidence for linkage was detected according to standard guidelines for linkage studies [28]. However, several loci displayed suggestive evidence for linkage and have provided valuable starting points for follow-up association studies.

The first genome scan was performed by Hanna et al. [22]. These authors analyzed 56 family members from seven pedigrees, each ascertained via a child with OCD. Of the relatives, 27 also had a lifetime diagnosis of OCD. As much as 349 microsatellite markers were used (with an average between-marker distance of $11.3 \mathrm{cM}$ ). The maximum multipoint LOD (logarithm of the odds) score was found to be 2.25 on 9p24 (marker D9S288) using a dominant model. Evidence for linkage to 9p24 was also supported by Willour et al. [58], who in order to replicate the findings of Hanna et al. [22] genotyped 50 pedigrees based on OCD index patients (42 sib pairs, 8 trios; altogether 193 subjects), using microsatellite markers spanning only the 9p24-region [58]. These authors found their strongest results for two markers (D9S1792, D9S1813) located within $0.5 \mathrm{cM}$ of the initial marker D9S288 [22]. Although the eight trio pedigrees were not informative for the linkage analysis, they were included in the 9p24 association analysis, which identified two markers (D9S288 and GATA62F03) with $p$-values of $<0.05$ (Willour et al. [58]) using the pedigree-disequilibrium test. It is noteworthy that $93 \%$ of the probands of this study had an early age of onset $(<16$ years of age), which was comparable to that $(<14$ years of age) in the sample of Hanna et al. [22].

Shugart et al. [46] studied a sample of 219 families (sib pairs and extended families). Multipoint analysis uncovered several suggestive linkage signals on chromosomes 3q27-28, 6q, 7p, 1q and 15q. Covariate linkage analyses implicated a possible role of a gene variant(s) on chromosome 1 in increasing the risk for an early-onset form of OCD [46]. The authors differentiated between the broad and narrow phenotypes and found linkage to $3 \mathrm{q} 27-28$ using the broad phenotype definition, which included definite and probable cases of OCD. The 3q27-28 region 
harbors, among others, the serotonergic genes HTR3C (5hydroxytryptamine [serotonin] receptor 3 , family member C), HTR $3 D$ and HTR3E. Hanna et al. [23] undertook another genome-wide linkage scan based on a total of 121 subjects, who were ascertained through 26 independent index patients with "early-onset" OCD (onset of OC symptoms before the age of 18 years). The maximum nonparametric $\log$ of odds (NLOD) score was 2.43 on chromosome 10p15 (marker D10S1745). However, the NLOD score on 10p15 decreased to 1.8 on inclusion of the data of their first genome scan [22]. Family-based association tests conducted with 35 SNPs in the 10p15 region provided evidence for association and linkage disequilibrium with three adjacent single-nucleotide polymorphisms (SNPs) in the $3^{\prime}$ region of the adenosine deaminase acting on RNA 3 gene (ADAR3). Interestingly, drosophila deletion mutants lacking ADAR activity have been observed to spend an inordinate amount of time in grooming throughout their life span [40]. The second highest NLOD score was 1.54 on chromosome 1 (at $126 \mathrm{cM}$ ), which was approximately $45-50 \mathrm{cM}$ proximal to the region 1q implicated in the genome scan of Shugart et al. [46].

\section{Association studies}

As described above, linkage studies have implicated several chromosomal regions, but the results have mostly been inconsistent. Only SNPs in the glutamate transporter gene SLC1A1 on 9p24 have been found to be associated with OCD, as based on a linkage finding. Otherwise, association studies have primarily focused on neurobiologically and pharmacologically plausible candidate genes such as SERT [SLC6A4], HTR1D, HTR2A, HTR2C, DRD4, DRD2, SLC1A1, GRIN2B, GABBRl, COMT, MAOA, TPH1, TPH2, BDNF, NTRK2, OLIG2 and MOG. Two reviews including candidate gene studies have recently been published by Pauls et al. [41] and Grados and Wilcox [19]. In contrast to both these publications, the next paragraph will focus on results based on children with OCD (see Table 3).

\section{Serotonergic system}

Selective serotonin re-uptake inhibitors block the serotonin transporter (SERT) and represent the most effective pharmacological treatment for OCD. Most association studies in OCD have therefore investigated serotonergic genes. The most frequently studied gene is SERT [SCL6A4] with its functional polymorphism in the upstream region termed 5-HTTLPR, which involves an insertion (L-[long] allele)/ deletion (S-[short] allele) polymorphism. In comparison with the S-allele, the L-allele has been reported to exert an increased transcriptional activity and an increased basal reuptake of $5-\mathrm{HT}$ in vitro $[24,31,37]$. The L-allele is therefore referred to as the gain-of-function variant of the serotonin transporter. Bloch et al. [9] reported a stratified meta-analysis investigating whether mean age of the sample (child vs. adult), ethnicity (Caucasian/Asian) and study design (case-control/family-based association studies) moderated any association. These authors found a significant association between the L-allele and OCD in familybased association studies (OR $=1.31 ; 95 \%$ CI: $1.02-1.69)$ and in studies involving Caucasian children $(\mathrm{OR}=1.41$; 95\% CI: 1.00-1.99), which might point to its specificity in early-onset OCD in Caucasians. In our own sample, we found a trend toward an association between the L-allele and early-onset OCD [53].

The 5-HTTLPR has been functionally refined by subdividing $\mathrm{L}$-alleles into the high-functioning $\mathrm{L}_{\mathrm{A}}$-alleles and lowfunctioning $\mathrm{L}_{\mathrm{G}}$-alleles. When this new classification is used, approximately $5-10 \%$ of L-alleles (depending on ethnicity) are low functioning and need to be grouped with the S-alleles for comparison purposes [25]. In our own sample of earlyonset OCD patients, we observed a significant overtransmission of the $\mathrm{L}_{\mathrm{A}}$-allele to affected offspring in 104 trios $(p=0.0054, \mathrm{OR}=2.06$; Wendland et al. under review [57]).

\section{Serotonin receptor subtypes}

The so-called HTR2 family consists of G-protein coupled receptors known as HTR2A and HTR2C. They are primarily associated with phospholipase $\mathrm{C}$, which catalyzes the hydrolysis of phosphatidylinositol bisphosphate (PIP2) and generates the second messenger molecules inositol triphosphate 3 (IP3) that mobilizes calcium from intracellular stores resulting in PKC activation and diacylglycerol (which potentiates PKC activation). PKC regulates numerous processes of cell function. For example, PKC activation causes a reduction in 5HT uptake capacity by phosphorylation and sequestration of 5HT transporter proteins [3]. The HTR2 subcategories have a widespread distribution in the brain [3].

Studies regarding association studies of the HTR $2 A$ polymorphisms (13q14-q21) in early-onset OCD are rare. In our sample of children and adolescents with OCD, we found in a case-control study an association of the A-allele of the 1438A/G (rs6311) locus with OCD [54]. These results pointed in the same direction as those of Enoch et al. $[16,17]$. These authors also described a correlation between the 1438A-allele and a retrospectively determined early onset of the disease [16, 17]. The results of these studies were more pronounced in female patients $[17,54]$.

The novel brain-specific tryptophan hydroxylase-2 (TPH2), the rate-limiting enzyme in 5-HT synthesis in the brain, was studied for association in OCD [35]. In this first study of TPH2 in OCD, rs4570625 and rs4565946 were significantly overtransmitted as a $\mathrm{G}-\mathrm{C}$ haplotype in 
Table 3 Results of association studies and meta-analyses in early-onset OCD

\begin{tabular}{|c|c|c|c|}
\hline Patient group, study design & $\begin{array}{l}\text { Gene SNP or } \\
\text { variant }\end{array}$ & Association & Studies \\
\hline Children/adolescents, case control & $\begin{array}{l}\text { 5-HT2A } \\
-1438 \mathrm{~A} / \mathrm{G} \\
\mathrm{rs} 6311\end{array}$ & Positive & Walitza et al. [54] \\
\hline Adults with early onset ${ }^{\mathrm{a}}$, case control & $\begin{array}{l}\text { 5-HT2A } \\
-1438 \mathrm{~A} / \mathrm{G} \\
\mathrm{rs} 6311\end{array}$ & Positive & Enoch et al. $[16,17]$ \\
\hline Children/adolescents, family based & $\begin{array}{l}\text { 5-HTTLPR } \\
\text { L-allele }\end{array}$ & Only a trend & Walitza et al. [53] \\
\hline $\begin{array}{l}\text { Meta-analysis adults and children, case } \\
\text { control and family based }\end{array}$ & $\begin{array}{l}\text { 5-HTTLPR } \\
\text { L-allele }\end{array}$ & $\begin{array}{l}\text { Positive for Caucasian children and in } \\
\text { family-based studies }\end{array}$ & Bloch et al. [9] \\
\hline Children/adolescents, family based & $\begin{array}{l}\text { 5-HTTLPR } \\
\mathrm{L}_{\mathrm{A}} \text {-allele }\end{array}$ & Positive & $\begin{array}{l}\text { Wendland et al. under review } \\
\text { [57] }\end{array}$ \\
\hline Children/adolescents, family based & $\begin{array}{l}\text { TPH2 } \\
\text { rs4570625 } \\
\text { rs4565946 }\end{array}$ & Overtransmission & Mossner et al. [35] \\
\hline Children/adolescents, family based & $\begin{array}{l}\text { DRD4 VNTR } \\
\text { 4-repeat allele }\end{array}$ & Undertransmission & Walitza et al. [52] \\
\hline Children/adolescents, family based & $\begin{array}{l}\text { COMT } \\
\text { Val158Met } \\
\text { rs } 4680\end{array}$ & No association & Walitza et al. [52] \\
\hline 164 triads including 38 children and adolescents & $\begin{array}{l}\text { BDNF } \\
\text { Val66Met } \\
\text { rs6265 }\end{array}$ & Positive & Hall et al. [20] \\
\hline Children/adolescents, family based & BDNF & No association & Mossner et al. [36] \\
\hline $\begin{array}{l}138 \text { adults and } 19 \text { children/adolescents, } \\
\text { family based }\end{array}$ & $\begin{array}{l}\text { SLC1A1 } \\
\text { rs301434 }\end{array}$ & Positive & Arnold et al. [6] \\
\hline Children/adolescents, family based & $\begin{array}{l}\text { SLC1A1 } \\
\text { rs3780412 } \\
\text { rs301430 }\end{array}$ & Overtransmission & Dickel et al. [13] \\
\hline Children/adolescents & $\begin{array}{l}\text { SLC1A1 } \\
\text { rs3780412 } \\
\text { rs2228622 } \\
\text { haplotype including } \\
\text { rs } 12682807 \\
\text { rs20772657 } \\
\text { rs } 3011430\end{array}$ & $\begin{array}{l}\text { Overtransmission to male offspring } \\
\text { Positive association }\end{array}$ & Stewart et al. [47] \\
\hline
\end{tabular}

a The patients retrospectively had predominately reported an early onset of OCD

children and adolescents with OCD. Moreover, a trend toward preferential transmission of the C-allele of rs4565946 in affected offspring was found. The genotype relative-risk estimate for homozygous $\mathrm{C}$-allele carriers of rs4565946 was 2.58 (95\% CI: 0.98-6.82).

Dopaminergic system

Obsessive-compulsive disorder patients, who are nonresponders to SSRIs, sometimes show clinical improvement following low-dose neuroleptic treatment, suggesting a dopaminergic role in OCD and therefore justifying the investigation of dopamine-related candidate genes. Several studies analyzed the variable number of tandem repeats (VNTR) of the dopamine-receptor D4 (DRD4) gene based on a 48-base pair repeat in exon III. In early-onset OCD, the most commonly observed four-repeat allele was found to be undertransmitted in trios, while no significant finding was observed for the seven-repeat allele [52]. Catecholamine- $O$-methyltransferase (COMT) is an 
enzyme involved in the metabolism of dopamine and a key modulator of dopaminergic neurotransmission. A $\mathrm{G}>\mathrm{A}$ substitution in codon 158 of COMT (Val158Met, rs4680) causes a three- to four-fold reduction of COMT activity and has been extensively studied for its association with OCD. We detected no evidence of transmission disequilibrium for COMT in early-onset OCD [52]. Another study of 261 adult patients with OCD (reported age at onset range: 2-51 years, mean age at investigation: 17.8 years) described an association of early-onset OCD and Met/Met genotype of COMT in a symptom cluster termed "Obsessional/checking" according to the Yale-Brown ObsessiveCompulsive Symptoms Checklist [33]. This symptom cluster included sexual, religious, somatic and harm-related obsessions as well as a variety of related compulsions (e.g., checking).

\section{Glutamatergic system}

The neuronal glutamate transporter gene (SLC1A1) on 9p24 is one of the few candidate genes for OCD that was investigated due to its localization within a linkage peak (see above). The role of this glutamate transporter gene in OCD is supported by the observation that the anti-glutamatergic drug riluzole can be beneficial in the treatment of OCD [43] and by the finding of elevated glutamate levels in the cerebrospinal fluid of OCD patients [12]. Shortly before SLC1A1 was proposed as a 9p24 positional candidate, Veenstra-VanderWeele [51] performed a mutation screen and family-based association of $S L C 1 A 1$ with primarily negative results. Five years later, Arnold et al. [6] detected an association of several markers spanning SLC1A1 with OCD in a sample of mostly adults and Dickel et al. [13] in children and adolescents. The association of SLC1A1 with OCD was corroborated at the haplotype and single-marker level by three other studies [32, $47,56]$. It should be noted, however, that all of the five positive SLC1A1 association studies in OCD used markers that only partially overlapped, and the findings regarding some of the few markers that were genotyped in more than one study were not consistently replicated. This inconsistency and the fact that the association described by Stewart et al. [47] in children and Wendland et al. [56] in adults pertains to haplotypes suggest that there are additional functional and possibly causal variants within the SLC1A1 region for OCD. It should further be noted that SLC1A1 also acts as a cysteine transporter and that transgenic mice with the disrupted orthologous gene Slclal display grooming abnormalities with increasing age [4]. It is also noteworthy that Arnold et al. [5] have reported an association of a glutamatergic receptor gene $(G R I N 2 B)$ with early-onset OCD. Further studies of glutamatergic neurons and SLC1A1, in particular, are therefore warranted in early- and adult-onset OCD.
Neurotrophic factors and transcription factors

Brain-derived neurotrophic factor (BDNF) promotes neuronal proliferation, regeneration and connectivity during development and participates in the plasticity and maintenance of neurons throughout adulthood. In addition, the neurotrophic tyrosine kinase (Trk) receptor type 2 (NTRK2) is highly linked to the activation of BDNF. Of special interest is the $B D N F$ Val66Met (rs6265) polymorphism, since this substitution may either influence the processing of the mature form or affect the interaction of the secreted and extracellularly processed pre-pro form with p75 NTR, thus modulating apoptotic signaling through this alternate pathway. Hall et al. [20] studied a number of four SNPs including Val66Met (rs 6165) spread over a distance of $56 \mathrm{~kb}$ at the $B D N F$ gene in 164 triads with OCD. They described evidence of association for all the markers. This finding is also of interest because the sample included 38 cases of early-onset OCD. Only in the group of early-onset OCD and in the total group, but not in the group consisting only of late-onset OCD, significant associations were observed. However, later studies did not find an association between OCD and BNDF [2, 36, 55, 59].

Additional evidence for the possible involvement of neurotrophic pathways stems from the association of two SNPs in the $3^{\prime}$ downstream region of NTRK2 (rs1017412 and rs7176429) with OCD $(\mathrm{OR}=2.16$ and 2.78 , respectively) [2].

The gene for oligodendrocyte lineage transcription factor 2 (OLIG2), located on $21 \mathrm{q} 22.11$, is an essential regulator in the development of human cells that produce white matter (myelin). In a family-based association study, three SNPs (rs762178, rs1059004 and rs9653711) within OLIG2 were associated with OCD without Tourette syndrome [47]. This finding awaits confirmation in future studies.

\section{Conclusion}

Like other psychiatric disorders, OCD is a complex disorder and its pathogenesis is most likely influenced by both genetic and environmental factors. Ongoing genome-wide association studies may shed new insight into the molecular genetic etiology of OCD. Possible gene-environment interactions include the moderation by a functional polymorphism of the risk for developing OCD following exposure to a traumatic event or an effect of a functional polymorphism on the development of a personality/neurocognitive profile that may predispose a person to OCD following environmental stress. An improved understanding of the OCD phenotype and the underlying etiological mechanisms may require novel approaches in the 
conceptualization of the disorder. These approaches include (1) narrowing the phenotype to identify categorically defined more homogeneous and mutually exclusive subtypes of OCD, (2) considering OC symptom dimensions as quantitative components of the more complex OCD phenotype and (3) broadening the phenotype to include other etiologically related conditions [34]. More elaborate phenotyping including age at onset, disease severity and dimensional measures [29] are therefore needed. Finally, the definition of endophenotypes through neuropsychological, neurophysiological and neuroimaging studies may contribute to the understanding of the genetic factors underlying OCD.

\section{References}

1. Albert U, Maina G, Ravizza L, Bogetto F (2002) An exploratory study on obsessive-compulsive disorder with and without a familial component: are there any phenomenological differences? Psychopathology 35:8-16

2. Alonso P, Gratacos M, Menchon JM, Saiz-Ruiz J, Segalas C, Baca-Garcia E, Labad J, Fernandez-Piqueras J, Real E, Vaquero C, Perez M, Dolengevich H, Gonzalez JR, Bayes M, de Cid R, Vallejo J, Estivill X (2008) Extensive genotyping of the BDNF and NTRK2 genes define protective haplotypes against obsessive-compulsive disorder. Biol Psychiatry 63:619-628

3. Aouizerate B, Guehl D, Cuny E, Rougier A, Burbaud P, Tignol J, Bioulac B (2005) Updated overview of the putative role of the serotoninergic system in obsessive-compulsive disorder. Neuropsychiatric Dis Treat 1:231-243

4. Aoyama K, Suh SW, Hamby AM, Liu J, Chan WY, Chen Y, Swanson RA (2006) Neuronal glutathione deficiency and agedependent neurodegeneration in the EAAC1 deficient mouse. Nat Neurosci 9:119-126

5. Arnold PD, Rosenberg DR, Mundo E, Tharmalingam S, Kennedy JL, Richter MA (2004) Association of a glutamate (NMDA) subunit receptor gene (GRIN2B) with obsessive-compulsive disorder: a preliminary study. Psychopharmacology (Berl) 174:530-538

6. Arnold PD, Sicard T, Burroughs E, Richter MA, Kennedy JL (2006) Glutamate transporter gene SLC1A1 associated with obsessive-compulsive disorder. Arch Gen Psychiatry 63:769-776

7. Bellodi L, Sciuto G, Diaferia G, Ronchi P, Smeraldi E (1992) Psychiatric disorders in the families of patients with obsessivecompulsive disorder. Psychiatry Res 42:111-120

8. Black DW, Noyes R Jr, Goldstein RB, Blum N (1992) A family study of obsessive-compulsive disorder. Arch Gen Psychiatry 49:362-368

9. Bloch MH, Landeros-Weisenberger A, Rosario MC, Pittenger C, Leckman JF (2008) Meta-analysis of the symptom structure of obsessive-compulsive disorder. Am J Psychiatry 165:1532-1542

10. Bolton D, Rijsdijk F, O'Connor TG, Perrin S, Eley TC (2007) Obsessive-compulsive disorder, tics and anxiety in 6-year-old twins. Psychol Med 37:39-48

11. Chabane N, Delorme R, Millet B, Mouren MC, Leboyer M, Pauls D (2005) Early-onset obsessive-compulsive disorder: a subgroup with a specific clinical and familial pattern? J Child Psychol Psychiatry 46:881-887

12. Chakrabarty K, Bhattacharyya S, Christopher R, Khanna S (2005) Glutamatergic dysfunction in OCD. Neuropsychopharmacology 30:1735-1740
13. Dickel DE, Veenstra-VanderWeele J, Cox NJ, Wu X, Fischer DJ, Van Etten-Lee M, Himle JA, Leventhal BL, Cook EH Jr, Hanna GL (2006) Association testing of the positional and functional candidate gene SLC1A1/EAAC1 in early-onset obsessive-compulsive disorder. Arch Gen Psychiatry 63:778-785

14. do Rosario-Campos MC, Leckman JF, Curi M, Quatrano S, Katsovitch L, Miguel EC, Pauls DL (2005) A family study of early-onset obsessive-compulsive disorder. Am J Med Genet B Neuropsychiatr Genet 136B:92-97

15. Eley TC, Bolton D, O'Connor TG, Perrin S, Smith P, Plomin R (2003) A twin study of anxiety-related behaviours in pre-school children. J Child Psychol Psychiatry 44:945-960

16. Enoch MA, Goldman D, Barnett R, Sher L, Mazzanti CM, Rosenthal NE (1999) Association between seasonal affective disorder and the 5-HT2A promoter polymorphism, -1438G/A. Mol Psychiatry 4:89-92

17. Enoch MA, Greenberg BD, Murphy DL, Goldman D (2001) Sexually dimorphic relationship of a 5-HT2A promoter polymorphism with obsessive-compulsive disorder. Biol Psychiatry 49:385-388

18. Flament MF, Whitaker A, Rapoport JL, Davies M, Berg CZ, Kalikow K, Sceery W, Shaffer D (1988) Obsessive compulsive disorder in adolescence: an epidemiological study. J Am Acad Child Adolesc Psychiatry 27:764-771

19. Grados M, Wilcox HC (2007) Genetics of obsessive-compulsive disorder: a research update. Expert Rev Neurother 7:967-980

20. Hall D, Dhilla A, Charalambous A, Gogos JA, Karayiorgou M (2003) Sequence variants of the brain-derived neurotrophic factor (BDNF) gene are strongly associated with obsessive-compulsive disorder. Am J Hum Genet 73:370-376

21. Hanna GL, Himle JA, Curtis GC, Gillespie BW (2005) A family study of obsessive-compulsive disorder with pediatric probands. Am J Med Genet B Neuropsychiatr Genet 134B:13-19

22. Hanna GL, Veenstra-VanderWeele J, Cox NJ, Boehnke M, Himle JA, Curtis GC, Leventhal BL, Cook EH Jr (2002) Genome-wide linkage analysis of families with obsessive-compulsive disorder ascertained through pediatric probands. Am J Med Genet 114:541-552

23. Hanna GL, Veenstra-Vanderweele J, Cox NJ, Van Etten M, Fischer DJ, Himle JA, Bivens NC, Wu X, Roe CA, Hennessy KA, Dickel DE, Leventhal BL, Cook EH Jr (2007) Evidence for a susceptibility locus on chromosome 10p15 in early-onset obsessive-compulsive disorder. Biol Psychiatry 62:856-862

24. Heils A, Teufel A, Petri S, Stober G, Riederer P, Bengel D, Lesch KP (1996) Allelic variation of human serotonin transporter gene expression. J Neurochem 66:2621-2624

25. Hu XZ, Lipsky RH, Zhu G, Akhtar LA, Taubman J, Greenberg BD, Xu K, Arnold PD, Richter MA, Kennedy JL, Murphy DL, Goldman D (2006) Serotonin transporter promoter gain-of-function genotypes are linked to obsessive-compulsive disorder. Am J Hum Genet 78:815-826

26. Hudziak JJ, Van Beijsterveldt CE, Althoff RR, Stanger C, Rettew DC, Nelson EC, Todd RD, Bartels M, Boomsma DI (2004) Genetic and environmental contributions to the Child Behavior Checklist Obsessive-Compulsive Scale: a cross-cultural twin study. Arch Gen Psychiatry 61:608-616

27. Kessler RC, Berglund P, Demler O, Jin R, Merikangas KR, Walters EE (2005) Lifetime prevalence and age-of-onset distributions of DSM-IV disorders in the National Comorbidity Survey Replication. Arch Gen Psychiatry 62:593-602

28. Lander E, Kruglyak L (1995) Genetic dissection of complex traits: guidelines for interpreting and reporting linkage results. Nat Genet 11:241-247

29. Leckman JF, Zhang H, Alsobrook JP, Pauls DL (2001) Symptom dimensions in obsessive-compulsive disorder: toward quantitative phenotypes. Am J Med Genet 105:28-30 
30. Lenane MC, Swedo SE, Leonard H, Pauls DL, Sceery W, Rapoport JL (1990) Psychiatric disorders in first-degree relatives of children and adolescents with obsessive compulsive disorder. J Am Acad Child Adolesc Psychiatry 29:407-412

31. Lesch KP, Bengel D, Heils A, Sabol SZ, Greenberg BD, Petri S, Benjamin J, Muller CR, Hamer DH, Murphy DL (1996) Association of anxiety-related traits with a polymorphism in the serotonin transporter gene regulatory region. Science 274:1527-1531

32. Liang KY, Wang Y, Shugart YY, Grados M, Fyer AJ, Rauch S, Murphy D, McCracken J, Rasmussen S, Cullen B, Hoehn-Saric R, Greenberg B, Pinto A, Knowles J, Piacentini J, Pauls D, Bienvenu O, Riddle M, Samuels J, Nestadt G (2008) Evidence for potential relationship between SLC1A1 and a putative genetic linkage region on chromosome $14 \mathrm{q}$ to obsessive-compulsive disorder with compulsive hoarding. Am J Med Genet B Neuropsychiatr Genet 147B:1000-1002

33. Lochner C, Hemmings SM, Kinnear CJ, Nel D, Seedat S, Moolman-Smook JC, Stein DJ (2008) Cluster analysis of obsessive-compulsive symptomatology: identifying obsessive-compulsive disorder subtypes. Isr J Psychiatry Relat Sci 45:164-176

34. Miguel EC, Leckman JF, Rauch S, do Rosario-Campos MC, Hounie AG, Mercadante MT, Chacon P, Pauls DL (2005) Obsessive-compulsive disorder phenotypes: implications for genetic studies. Mol Psychiatry 10:258-275

35. Mossner R, Walitza S, Geller F, Scherag A, Gutknecht L, Jacob C, Bogusch L, Remschmidt H, Simons M, Herpertz-Dahlmann B, Fleischhaker C, Schulz E, Warnke A, Hinney A, Wewetzer C, Lesch KP (2006) Transmission disequilibrium of polymorphic variants in the tryptophan hydroxylase- 2 gene in children and adolescents with obsessive-compulsive disorder. Int $\mathbf{J}$ Neuropsychopharmacol 9:437-442

36. Mossner R, Walitza S, Lesch KP, Geller F, Barth N, Remschmidt H, Hahn F, Herpertz-Dahlmann B, Fleischhaker C, Schulz E, Warnke A, Hinney A, Wewetzer C (2005) Brain-derived neurotrophic factor V66M polymorphism in childhood-onset obsessivecompulsive disorder. Int J Neuropsychopharmacol 8:133-136

37. Murphy DL, Lesch KP (2008) Targeting the murine serotonin transporter: insights into human neurobiology. Nat Rev Neurosci 9:85-96

38. Nestadt G, Samuels J, Riddle M, Bienvenu OJ 3rd, Liang KY, LaBuda M, Walkup J, Grados M, Hoehn-Saric R (2000) A family study of obsessive-compulsive disorder. Arch Gen Psychiatry 57:358-363

39. Nicolini H, Weissbecker K, Mejia JM, Sanchez de Carmona M (1993) Family study of obsessive-compulsive disorder in a Mexican population. Arch Med Res 24:193-198

40. Palladino MJ, Keegan LP, O'Connell MA, Reenan RA (2000) dADAR, a drosophila double-stranded RNA-specific adenosine deaminase is highly developmentally regulated and is itself a target for RNA editing. RNA 6:1004-1018

41. Pauls DL (2008) The genetics of obsessive compulsive disorder: a review of the evidence. Am J Med Genet C Semin Med Genet 148C:133-139

42. Pauls DL, Alsobrook JP 2nd, Goodman W, Rasmussen S, Leckman JF (1995) A family study of obsessive-compulsive disorder. Am J Psychiatry 152:76-84

43. Pittenger C, Krystal JH, Coric V (2006) Glutamate-modulating drugs as novel pharmacotherapeutic agents in the treatment of obsessive-compulsive disorder. NeuroRx 3:69-81

44. Reddy PS, Reddy YC, Srinath S, Khanna S, Sheshadri SP, Girimaji SR (2001) A family study of juvenile obsessive-compulsive disorder. Can J Psychiatry 46:346-351

45. Riddle MA, Scahill L, King R, Hardin MT, Towbin KE, Ort SI, Leckman JF, Cohen DJ (1990) Obsessive compulsive disorder in children and adolescents: phenomenology and family history. J Am Acad Child Adolesc Psychiatry 29:766-772
46. Shugart YY, Samuels J, Willour VL, Grados MA, Greenberg BD, Knowles JA, McCracken JT, Rauch SL, Murphy DL, Wang Y, Pinto A, Fyer AJ, Piacentini J, Pauls DL, Cullen B, Page J, Rasmussen SA, Bienvenu OJ, Hoehn-Saric R, Valle D, Liang KY, Riddle MA, Nestadt G (2006) Genomewide linkage scan for obsessive-compulsive disorder: evidence for susceptibility loci on chromosomes 3q, 7p, 1q, 15q, and 6q. Mol Psychiatry 11:763-770

47. Stewart SE, Fagerness JA, Platko J, Smoller JW, Scharf JM, Illmann C, Jenike E, Chabane N, Leboyer M, Delorme R, Jenike MA, Pauls DL (2007) Association of the SLC1A1 glutamate transporter gene and obsessive-compulsive disorder. Am J Med Genet B Neuropsychiatr Genet 144B:1027-1033

48. Stewart SE, Geller DA, Jenike M, Pauls D, Shaw D, Mullin B, Faraone SV (2004) Long-term outcome of pediatric obsessivecompulsive disorder: a meta-analysis and qualitative review of the literature. Acta Psychiatr Scand 110:4-13

49. Valleni-Basile LA, Garrison CZ, Jackson KL, Waller JL, McKeown RE, Addy CL, Cuffe SP (1994) Frequency of obsessive-compulsive disorder in a community sample of young adolescents. J Am Acad Child Adolesc Psychiatry 33:782-791

50. van Grootheest DS, Cath DC, Beekman AT, Boomsma DI (2005) Twin studies on obsessive-compulsive disorder: a review. Twin Res Hum Genet 8:450-458

51. Veenstra-VanderWeele J, Kim SJ, Gonen D, Hanna GL, Leventhal BL, Cook EH Jr (2001) Genomic organization of the SLC1A1/EAAC1 gene and mutation screening in early-onset obsessive-compulsive disorder. Mol Psychiatry 6:160-167

52. Walitza S, Scherag A, Renner TJ, Hinney A, Remschmidt H, Herpertz-Dahlmann B, Schulz E, Schafer H, Lange KW, Wewetzer C, Gerlach M (2008) Transmission disequilibrium studies in early onset of obsessive-compulsive disorder for polymorphisms in genes of the dopaminergic system. J Neural Transm 115:1071-1078

53. Walitza S, Wewetzer C, Gerlach M, Klampfl K, Geller F, Barth N, Hahn F, Herpertz-Dahlmann B, Gossler M, Fleischhaker C, Schulz E, Hebebrand J, Warnke A, Hinney A (2004) Transmission disequilibrium studies in children and adolescents with obsessive-compulsive disorders pertaining to polymorphisms of genes of the serotonergic pathway. J Neural Transm 111:817-825

54. Walitza S, Wewetzer C, Warnke A, Gerlach M, Geller F, Gerber G, Gorg T, Herpertz-Dahlmann B, Schulz E, Remschmidt H, Hebebrand J, Hinney A (2002) 5-HT2A promoter polymorphism $-1438 \mathrm{G} / \mathrm{A}$ in children and adolescents with obsessive-compulsive disorders. Mol Psychiatry 7:1054-1057

55. Wendland JR, Kruse MR, Cromer KR, Murphy DL (2007) A large case-control study of common functional SLC6A4 and BDNF variants in obsessive-compulsive disorder. Neuropsychopharmacology 32:2543-2551

56. Wendland JR, Moya PR, Timpano KR, Anavitarte AP, Kruse MR, Wheaton MG, Ren-Patterson RF, Murphy DL (2009) A haplotype containing quantitative trait loci for SLC1A1 gene expression and its association with obsessive-compulsive disorder. Arch Gen Psychiatry 66:408-416

57. Wendland JR, Nalls MA, Moya PR, Murphy DL, McMahon FJ, Remschmidt H, Herpertz-Dahlmann B, Schulz E, Renner TJ, Walitza S (2010, under review) Trio study and support the association of the serotonin transporter 5-HTTLPR gain-offunctional allele with obsessive-compulsive disorder

58. Willour VL, Yao Shugart Y, Samuels J, Grados M, Cullen B, Bienvenu OJ 3rd, Wang Y, Liang KY, Valle D, Hoehn-Saric R, Riddle M, Nestadt G (2004) Replication study supports evidence for linkage to 9p24 in obsessive-compulsive disorder. Am J Hum Genet 75:508-513

59. Zai G, Bezchlibnyk YB, Richter MA, Arnold P, Burroughs E, Barr CL, Kennedy JL (2004) Myelin oligodendrocyte glycoprotein (MOG) gene is associated with obsessive-compulsive disorder. Am J Med Genet B Neuropsychiatr Genet 129B:64-68 